\title{
WOJSKO A LUDNOŚĆ CYWILNA NA PRZYKŁADZIE GARNIZONU KRAKOWSKIEGO W DOBIE NAPOLEOŃSKIEJ
}

\author{
Michał Baczkowski \\ Uniwersytet Jagielloński w Krakowie
}

\author{
ABSTRACT \\ THE MILITARY AND THE CIVILIANS: A CASE OF THE CRACOW'S \\ GARRISON IN THE NAPOLEONIC ERA
}

Cracow played an important military role at the turn of the $19^{\text {th }}$ century. Since 1796 an Austrian garrison was stationed there, in the years 1809-1813 a Polish one, and during 1813-1815 the town was occupied by the Russian army. Military barracks, warehouses and hospitals were established in the city. The military garrison counted several thousand soldiers. The maximum number of them was recorded in 1807-1809 (about 6,000). Relations between the army and the civilian population were difficult. The military drew various benefits from the city and levied taxes on it. The most difficult problem was the accommodation of soldiers in private apartments. It caused many misunderstandings and conflicts. Excessive exploitation of the city by the Polish army in 1809 led to a decrease in the number of inhabitants. The Russian army (1813-1815), however, treated the inhabitants as enemies which resulted in violence against the civilians. The demilitarization of Cracow in 1815 was welcomed by the inhabitants with great joy.

Key words: history of the military of the $18^{\text {th }}$ and $19^{\text {th }}$ centuries, history of Cracow, civilian population against the army.

Słowa kluczowe: dzieje wojskowości XVIII-XIX wieku, historia Krakowa, ludność cywilna wobec wojska.

Przełom XVIII i XIX wieku w Europie to czas wojen, mobilizacji wojskowych i nasilonej militaryzacji niemal wszystkich państw kontynentu. Na skutek wojen z rewolucyjną, a następnie napoleońską Francją podporządkowano różne aspekty życia cywilnego potrzebom wojskowym, a czynnik militarny zdominował kwestie gospodarcze, polityczne oraz kulturalne epoki. Problem ten dotyczył nie tylko stolic wielkich mocarstw, ważnych twierdz i bezpośredniego zaplecza frontowego, ale także ośrodków miejskich znajdujących się na uboczu wielkich zmagań. Do nich należał właśnie Kraków. 
W latach 1796-1815 Kraków pełnił funkcję ważnego ośrodka garnizonowego w skali ponadregionalnej. Bezpośredni wpływ na funkcje militarne miasta miały zarówno wydarzenia natury politycznej (upadek Rzeczypospolitej i wcielenie Krakowa do Austrii, następnie do Księstwa Warszawskiego, a wreszcie okupacja rosyjska), jak i czysto militarnej. Te ostatnie dotyczyły najczęściej bezpośrednio ziem znacznie oddalonych od miasta pod Wawelem, ale ostatecznie odbijały się na sytuacji samego Krakowa. Wskutek klęsk zadanych Austrii przez Napoleona Bonapartego ściągnięto do miasta habsburskie regimenty wypuszczone „na słowo" z niewoli, następnie (1801-1802) rozlokowano tu pułki pochodzące z utraconych ziem (Niderlandów, Lombardii). Wreszcie w styczniu 1806 roku skoncentrowano tu niedobitki armii cofającej się spod Austerlitz. Przez miasto dwukrotnie przeszły wojska rosyjskie maszerujące z nadzieją na zwycięstwo nad Francją $(1799,1805)$, a następnie ich pokonane oddziały wracające do ojczyzny $(1800,1805-1806)$. W następnych latach sytuacja wyglądała podobnie. Po wkroczeniu wojsk napoleońskich na ziemie polskie zaboru pruskiego jesienią 1806 roku bardzo poważnie zwiększono stan załogi austriackiej w mieście, a w przededniu kampanii 1809 roku przez Kraków przemaszerował VII Korpus Austriacki arcyksięcia Ferdynanda d'Este, przygotowując się do agresji na Księstwo Warszawskie ${ }^{1}$. W wyniku opanowania miasta w lipcu tego roku przez wojsko polskie dawna stolica Rzeczypospolitej stała się na wiele miesięcy jednym z ważniejszych punktów strategicznych Księstwa Warszawskiego². W maju 1811 roku wycofano stąd większość oddziałów liniowych, które wróciły tu dopiero w lutym 1813 roku po przegranej wyprawie na Moskwę. W ciągu kolejnych trzech miesięcy Kraków był punktem zbornym odbudowujących się wojsk polskich. Po ich wymarszu do Saksonii został zajęty bez walk w maju tego roku przez oddziały rosyjskie. Okupacja rosyjska trwała ponad dwa lata i zakończyła się dopiero kilka miesięcy po proklamowaniu Wolnego Miasta Krakowa. Dla Rosji Kraków stanowił istotny punkt etapowy i magazynowy na osi Kijów-Drezno-Paryż, przez który przemieszczały się masy wojsk carskich w trakcie i po zakończeniu dwóch ostatnich kampanii antynapoleońskich $(1813-1814,1815)^{3}$.

Przełom XVIII i XIX wieku był zatem dla mieszkańców Krakowa okresem szczególnym, charakteryzującym się gwałtownym wzrostem znaczenia czynnika

1 Szerzej na temat pochodzenia austriackich oddziałów załogi krakowskiej oraz ulokowanych tu dowództw wojskowych zob.: Österreichischer Militär Almanach, 1797-1803 (następnie pod nazwą Schematismus der Kais. Königl. Armée: für das Jahr, 1804-1809), Wien 1797-1809; A. von Wrede, Geschichte der k. u. k. Wehrmacht, Bd. I-III, Wien 1898-1901, wykazy pułków; a także: G. Amon von Treuenfest, Geschichte des k.k. Infanterie-Regiments Nr. 20 Friedrich Wilhelm Kronprinz des Deutschen Reich und Kronprinz von Preussen, Wien 1878; J. Kreipner, Geschichte des k. und k. Infanterie-Regimentes Nr. 34 für immerwährende Zeiten Wilhelm I Deutscher Kaiser und König von Preussen 1733-1900, Wien 1900; Geschichte des kaiserlichen und königlichen Infanterie-Regiment Freiherr von Mollinary Nr. 38, seit seiner Errichtung 1725 bis 1891, Budapest 1892; W. Bichmann, Chronik des k.k. Infanterie-Regiments Nr. 62 dermalen Ludwig Prinz von Bayern von seiner Errichtung 1798 bis 1880, Wien 1880.

Zob. B. Pawłowski, Wojna polsko-austriacka 1809 r., Warszawa 1999, s. 432-436; K. Krzos, Z księciem Józefem w Galicji w 1809 roku. Rząd Centralny Obojga Galicji, Warszawa 1967, s. 178-185.

3 Zob. Archiwum Narodowe w Krakowie (dalej: ANK), Magistrat Krakowa I (dalej: Mag I), 225. 
militarnego w mieście. Wojsko wpływało wówczas bezpośrednio na przemiany ekonomiczne, urbanistyczne, demograficzne, a także w pewien sposób na kwestie narodowościowe i społeczne. Stało się jednym z czynników przemian i modernizacji przestrzeni miejskiej pod względem prawnym, mentalnościowym oraz infrastrukturalnym.

Garnizon odgrywał wówczas istotną rolę także z powodu swojej znacznej liczebności w stosunku do potencjału ludności cywilnej Krakowa. Ta ostatnia wzrosła z niespełna $22000 \mathrm{w} 1796$ roku do ponad $27500 \mathrm{w} 1808$ roku. W wyniku wojny 1809 roku i zmian politycznych nastąpił gwałtowny spadek zaludnienia do poziomu nieco ponad 23000 mieszkańców, a liczba ta utrzymała się do 1815 roku. Stan osobowy wojska w tym okresie był zmienny. W latach 1797-1801 przebywało tu od 800 do 1800 żołnierzy habsburskich, w latach 1802-1803 - ponad 2000, w 1804 roku 3000, w 1806 roku - od 3500 do 10 000, w latach 1807-1809 - od 5300 do 6100. Garnizon polski funkcjonujący w latach 1809-1813 charakteryzował się jeszcze większą dynamiką zmian. Jesienią 1809 roku stacjonowało w nim 6000 wojskowych, w następnym roku - 3000, a od połowy 1811 do początku 1813 roku - tylko kilkuset. Wiosną tego roku przejściowo przebywało w nim 5000 żołnierzy. Okupacyjna załoga rosyjska także charakteryzowała się bardzo znacznymi fluktuacjami składu. $\mathrm{Na}$ początku 1815 roku liczyła 2500 oficerów i żołnierzy, zwykle była jednak mniejsza. Ponadto w latach 1811-1815 funkcjonowała w mieście Gwardia Narodowa o nader zmiennym składzie i zróżnicowanych zadaniach ${ }^{4}$.

Podstawowe kontakty między wojskowymi a cywilami wynikały z:

- kwaterunku oficerów i żołnierzy w mieszkaniach prywatnych;

- realizacji przymusowych i dobrowolnych dostaw oraz zamówień dla wojska;

- uczestnictwa wojskowych w życiu towarzyskim i politycznym miasta;

- przestępczości pospolitej wojskowych i cywilów;

- konfliktów na tle narodowościowym i politycznym.

Administracja miejska obarczona została przez władze państwowe kilkoma zadaniami na rzecz wojska. Należały do nich: organizacja i zapewnienie kwaterunku, prowadzenie lub uczestnictwo w ewidencji popisowych i poborze rekruta, organizacja dostaw dla armii oraz pobieranie podatków na cele militarne. W ślad za tym różne funkcje służebne na rzecz wojska pełnić miała znaczna część mieszkańców, w tym wszyscy posiadacze nieruchomości.

Na jakość kontaktów pomiędzy wojskowymi a cywilami pewien wpływ miała także kwestia językowa. Problem ten nie istniał tylko w odniesieniu do wojsk polskich. W armii austriackiej teoretycznie cały korpus oficerski powinien płynnie władać niemieckim. W rzeczywistości dla części oficerów (głównie Szkotów, Flamandów, Węgrów) był to język obcy, który opanowali tylko w zakresie niezbędnym do wykonywania swoich obowiązków. Gorzej wyglądała sytuacja w odniesieniu do rekrutów. W omawianym okresie stacjonowały w Krakowie regimenty wywodzące się z Węgier, Siedmiogrodu, Niderlandów Austriackich (Belgii), Dolnej Austrii,

4 Szerzej zob.: M. Baczkowski, Wojsko austriackie w Krakowie w latach 1796-1809, Kraków 2007, s. 20-45; idem, Wojsko polskie w napoleońskim Krakowie, Kraków 2009, s. 43-58, 66-78. 
Styrii, Karyntii, Moraw, Śląska i Galicji ${ }^{5}$. Dla większości różnojęzycznych szeregowych niemiecki był językiem obcym, którego znajomość ograniczała się zapewne do rozumienia wydanych komend. Oddziały rosyjskie stacjonujące w mieście miały w swoim składzie oficerów pochodzenia polskiego, ale ich znajomość języka ojczystego, przynajmniej w świetle zachowanych nielicznych pism, okazała się co najmniej kiepska. Wśród szeregowców dominowali rekruci z południowych guberni rosyjskich oraz Kozacy Dońscy. Dla mieszkańców Krakowa drugim, po języku polskim, był niemiecki, rozpowszechniony przede wszystkim w kręgach kupieckich ${ }^{6}$. Tylko nieliczni znali francuski. Należy zatem założyć, że istniejąca bariera językowa, szczególnie w odniesieniu do rekrutów i osób z niższych warstw społecznych miasta, skutecznie utrudniała im nawiązanie bliższych kontaktów.

Najważniejszą i najbardziej zapalną sprawą przez cały omawiany okres pozostawała kwestia kwaterunku. Należy przy tym rozróżnić dwa modele prawne zapewnienia żołnierzom dachu nad głową. System austriacki, realizujący idee biurokratycznego państwa oświeconego absolutyzmu, wspomagającego zarazem rozwój miast, wprowadził zasadę współpracy monarchii i większych miast w tym zakresie oraz częściową rekompensatę finansową wypłacaną osobom dotkniętym wspomnianym ciężarem. W praktyce polegało to na tym, że państwo finansowało budowę obiektów koszarowych przynajmniej dla części szeregowych, oficerowie i pozostała grupa żołnierzy otrzymywali zaś przydział do mieszkań prywatnych. Właściciele nieruchomości uiszczali natomiast specjalny podatek, $\mathrm{z}$ którego wypłacano rekompensatę tym, do których mieszkań zakwaterowano wojskowych, oraz prowadzono bieżące remonty koszar? ${ }^{7}$. System prawny Księstwa Warszawskiego (obowiązujący także podczas okupacji rosyjskiej) nie przewidywał żadnych form rekompensat dla właścicieli dotkniętych kwaterunkiem, a państwo nie podjęło się budowy koszar ${ }^{8}$. W rezultacie obowiązek zapewnienia żołnierzom dachu nad głową spadał na miejscowości garnizonowe. Było to w jakimś stopniu odzwierciedleniem zmilitaryzowanego charakteru państwa, rządzonego przez środowisko arystokratyczno-ziemiańskie, w nikłym stopniu zainteresowane sytuacją miast.

Problem kwaterunku wojskowego dotknął większość chrześcijańskich właścicieli nieruchomości w Krakowie (na żydowskich nałożono dodatkowe podatki w zamian za zwolnienie z tego ciężaru). W wykazie z 16 stycznia 1809 roku znajdowało się 628 budynków objętych kwaterunkiem9. W domach tych zablokowany został wol-

5 A. von Wrede, Geschichte der k. u. k. Wehrmacht, Bd. I-III, wykazy pułków.

6 Świadczą o tym akta magistrackie, korespondencja elit miejskich, a także pochodzenie etniczne znacznej części krakowskiego patrycjatu, zob. ANK, Prefektura Departamentu Krakowskiego (dalej: PDK), 1, vol. 1, k. 2-9; vol. 2, k. 5; D. Re derowa, Studia nad wewnętrznymi dziejami Krakowa porozbiorowego (1796-1809), cz. II: Zagadnienia ustrojowe i ekonomiczno-społeczne, „Rocznik Krakowski” 1962, t. XXXVI, s. 30-31.

Zob. Instrukcja Hofkomission z 29 XI 1797, ANK, Mag I/229, s. 111-118; decyzję Gubernium z 27 VI 1806, ANK, Mag I/229, s. 871-882. Na temat ogólnych zasad systemu kwaterunkowego w Zachodniej Galicji: T. Mencel, Galicja Zachodnia 1796-1809. Studium z dziejów ziem polskich zaboru austriackiego po III rozbiorze, Lublin 1976, s. 149-150, 323-324.

8 ANK, Mag I/230, s. 475-513; D. Rederowa, op. cit., s. 41-43.

9 ANK, Mag I/782, s. 203-255. 
ny najem mieszkań, a na ich wynajęcie osobom cywilnym konieczna była zgoda magistratu $^{10}$. W rezultacie kwaterunek miał znaczący wpływ na działalność inwestycyjną właścicieli, przyczyniając się w pewnym stopniu do ożywienia ruchu budowlanego, gdyż nowo wznoszone budynki mieszkalne zostały na 10 lat zwolnione z kwaterunku. Dla zamożniejszych właścicieli system ten stwarzał korzystne warunki do bogacenia się, dla pozostałych oznaczał zablokowanie wszelkich możliwości rozwoju swojego gospodarstwa.

Władze austriackie wprowadziły program adaptacji na koszary i magazyny wojskowe części istniejących budynków państwowych (zamek na Wawelu), miejskich (m.in. ratusz kazimierski), kościelnych (kościół św. Szczepana i dawny nowicjat jezuitów, kościół św. Scholastyki, klasztory trynitarzy, bernardynów, dominikanów i kanoników laterańskich, seminarium biskupie) oraz uniwersyteckich (bursy, drukarnia). Nie były one jednak w stanie pomieścić całej załogi, a ich stan techniczny był daleki od ideału. W czasach Księstwa Warszawskiego administracja wojskowa zrezygnowała $\mathrm{z}$ dalszego wykorzystania tych obiektów poza zaadaptowaniem ich na cele lazaretowe; nowe wyposażenie lazaretów, ufundowane przez miasto, wywiozła w 1810 roku do Kielc, co wywołało ogromne rozgoryczenie mieszkańców i w dużym stopniu przyczyniło się do dyskredytacji działań polskich władz wojskowych. W sprawie tej interweniowali deputowani Krakowa na sejm Księstwa Warszawskiego (Antoni Morbitzer, Maciej Mączeński, Jan Kanty Krzyżanowski, ks. Karol Skórkowski) u Ministra Spraw Wewnętrznych w grudniu 1811 roku, ale bez skutku. Samo podjęcie tego problemu, i to w dość ostry sposób, ukazywało skalę niezadowolenia elit krakowskich z działań administracji wojskowej ${ }^{11}$.

Kwaterunek żołnierzy wywoływał nieustanne spory i awantury, kończące się skargami na oficerów i szeregowych, a w skrajnych przypadkach aktami przemocy wobec cywilów. Bez większego błędu można przyjąć, że właśnie na tym polegała większość kontaktów miedzy mieszkańcami Krakowa a wojskowymi austriackimi, polskimi i rosyjskimi w tej epoce ${ }^{12}$. Zazwyczaj podstawą sporu była jakość dostarczanych kwater oraz sposób realizacji zobowiązania właścicieli do zapewnienia żołnierzom wody i opału, a także udostępnienia kuchni. Nie stanowiło to jednak reguły. W wielu wypadkach stosunki między cywilami a mieszkającymi u nich wojskowymi układały się dobrze, czasami przechodząc nawet w pewną zażyłość. Rzecz jasna, wymagało to dobrej woli obydwu stron i gotowości pójścia na kompromis. O takich przypadkach źródła archiwalne najczęściej nie wspominają, a pojedyncze notki odnaleźć można głównie we wspomnieniach. Wszelkie sprawy sporne zostały nato-

10 ANK, Mag I/783, s. 177.

11 M. Baczkow ski, Wojsko austriackie..., s. 72-82; idem, Wojsko polskie..., s. 52; S. Tomkowicz, Wawel, t. I, Kraków 1908, s. 382-433; t. II, Kraków 1913, s. 763-768; ANK, Mag I/222, s. 15; ANK, Varia Krakowa i Okręgu Krakowskiego (dalej: VKOK), 607, s. 34; 608, s. 1.

12 ANK, Mag I/783, s. 11, 15, 53, 57, 73, 119-127, 133-135, 177, 269, 277, 455; Mag I/233, s. 17. Przykładem może być skarga Michała Lelowskiego na adiutanta feldmarszałka - porucznika Franza Xaviera Hohenzollerna-Hechingena: „gwałtem [pokoje] otworzyć kazał, szkalując i biciem grożąc gospodarzowi”, który „żadnej ani od stajni, ani od pokojów dotychczas zapłaty [nie ma], a podatki krajowe opłacać musi”. ANK, Mag I/783, s. 455. 
miast dość dokładnie odnotowane w aktach kwatermistrzostwa, a czasem w materiałach archiwalnych poszczególnych armii. Co z nich wynika?

W konflikty angażowały się osoby z najrozmaitszych warstw społecznych. Wśród cywilów wymienić można arystokratów i szlachtę osiadłą w Krakowie, zamożnych rzemieślników i ubogich właścicieli przedmiejskich domków. Najrzadziej spotkać można było natomiast osoby z elit kupieckich, współrządzących miastem. Ta grupa społeczna znajdowała się pod specjalną opieką władz miejskich. Po stronie wojskowej jako antagoniści występowali oficerowie sztabowi, oficerowie niższych stopni, adiutanci generalicji oraz szeregowcy. Podłoże sporów stanowiły przede wszystkim kwestie ekonomiczne, następnie te natury prestiżowej, a wreszcie kryminalnej. Cywile zarzucali wojskowym samowolny zabór najlepszych pokoi w mieszkaniach, wyrzucanie właścicieli z ich domów (chodziło głównie o małe budynki na przedmieściach), zajmowanie i dewastację stajni, przywłaszczanie mebli i innych obiektów gospodarskich, zabór sprzętów kuchennych oraz soli. Łączyły się z tym oskarżenia o lżenie, groźby, przypadki pobicia oraz zranienia niebezpiecznymi przedmiotami. Wojskowi natomiast udowodniali, że właściciele kwater z premedytacją udostępniali im najgorsze pomieszczenia, pozbawione elementarnego wyposażenia, blokowali możliwość korzystania z kuchni i uniemożliwiali prowadzenie normalnego trybu życia.

Szczególnie dużo zarzutów tego typu pochodziło z czasów Księstwa Warszawskiego. Oto przykłady: „gospodarz domu ogołocił wszystkie pokoje z meblów, że pułkownikowi [Benonowi] Łączyńskiemu tam stojącemu na kwaterze żadnego nawet nie pozostało zwierciadła i wiele brakuje rekwizytów”. Albo: ,gospodarz tameczny nie chce tego uczynić [gotować], wymawiając się śmiesznym sposobem, że mu służąca uciekła, ponieważ jej ordynans kapitana nie pilnował, a więc żąda, aby kapitan sam palił". W ciekawszej sytuacji znalazł się porucznik Maciej Żórawski, którego zakwaterowano w domu publicznym. Oficer skarżył się, że „osób takich współmieszkańcem być i na żarty publiczności wystawiać się nie może”. Ostatecznie w przybytku ,panien lubieżnych” w miejsce porucznika ulokowano zwykłych szeregowców ${ }^{13}$.

Zarzuty obydwu stron były w wielu wypadkach prawdziwe i dowodziły niesprawności obowiązującego modelu kwaterunkowego. Władze austriackie początkowo bardzo poważnie traktowały skargi mieszkańców Krakowa, doprowadzając nawet do aresztowania i degradacji najbardziej agresywnych wojskowych, w tym oficerów ${ }^{14}$. W następnych latach górę w tych konfliktach w coraz większym stopniu

13 ANK, Mag I/221, s. 187, 189, 589, 597, 696, 717. Problemy tego typu dotyczyły także innych miast Księstwa Warszawskiego, zob. H. Brandt, Moja slużba w Legii Nadwiślańskiej, Gdynia 2002, s. 157.

14 Najgłośniejszą sprawą było aresztowanie w 1796 r. por. Nozsacka z 4. Pułku Huzarów węgierskich za pobicie właściciela kwatery, jego żony i dziecka. Krewki oficer kazał swoim podkomendnym wymierzyć im kilkadziesiąt kijów. Wynikło to z nieporozumienia w kwestii opieki nad psem porucznika. $\mathrm{Na}$ skutek skargi mieszczanina Nozsack został skazany na degradację i dwa lata twierdzy. Nadworna Rada Wojenna podniosła karę do pięciu lat twierdzy, by zademonstrować mieszkańcom Krakowa poczucie sprawiedliwości władz cesarskich i pozyskać ich sympatię. Österreichisches Staatsarchiv/Kriegsarchiv Wien (dalej: ÖStA/KA), Kriegsminister Lacy Akten (dalej: KLA), fasc. 299/13, 302/11, 332/19. 
brała strona wojskowa. W przededniu i na początku wojny 1809 roku sądy wojskowe jednoznacznie dezawuowały zarzuty stawiane przez cywili. Praktyka ta w dużym stopniu przyczyniła się do całkowitej dyskredytacji władz austriackich i jednoznacznego poparcia wkraczających wojsk polskich przez mieszkańców Krakowa w lipcu $1809 \mathrm{roku}^{15}$.

W dobie Księstwa Warszawskiego zarzuty stawiane wojskowym były stosunkowo rzadkie. Wynikało to zapewne z przejęcia przez mieszkańców Krakowa napoleońskiej wizji rozwiązania sprawy polskiej i przyjęcia przez nich nowej opcji niepodległościowej. Aczkolwiek mieszczaństwo czuło się często szykanowane przez władze Księstwa Warszawskiego na gruncie gospodarczym, to jednak uznawało wojsko polskie za „swoją" armię, stąd też liczba skarg cywilów była niewielka. Zastanawiać może natomiast dość znaczna liczba zażaleń ze strony oficerów na oferowane im warunki kwaterowe i niechęć okazywaną im rzekomo przez samych mieszkańców. Wydaje się, że po części było to odbiciem przyzwyczajenia wojskowych do życia na wielkopańskiej stopie i przekonania o przynależności do elity stojącej ponad prawem oraz śladem starego konfliktu na linii szlachta-mieszczaństwo ${ }^{16}$. Inna rzecz, że zakwaterowanie oficerów w domu publicznym, a żołnierzy w ruderach pozbawionych przez właścicieli elementarnego wyposażenia, nie świadczyło najlepiej o pracy kwatermistrzostwa i postawie niektórych mieszkańców. Należy przy tym podkreślić, że władze Księstwa Warszawskiego nie wykorzystały koszar poaustriackich, lokując wszystkich wojskowych na kwaterach prywatnych, co dodatkowo wzbudziło rozgoryczenie ludności cywilnej. Decyzja ta wynikała zapewne ze względów finansowych, gdyż za utrzymanie wojskowych w prywatnych mieszkaniach skarb wojskowy nie ponosił żadnych opłat ${ }^{17}$.

O ile stosunki cywilów z kwaterującymi u nich wojskowymi polskimi były skomplikowane, ale nie pozbawione w wielu wypadkach obustronnej sympatii, o tyle relacje z oficerami i szeregowymi rosyjskimi, okupującymi Kraków w latach 18131815 , kształtowały się zupełnie inaczej. Obie strony uważały swoich partnerów, nie bez powodu, za wrogów. Okupacyjne władze rosyjskie formalnie uznawały system prawny Księstwa Warszawskiego, ale w razie jakichkolwiek sporów interpretowały zaistniałą sytuację na korzyść wojsk carskich ${ }^{18}$. Samo złożenie skargi przez kwatermistrza miejskiego wymagało nie lada odwagi, gdyż ten mógł zostać po prostu obity i zrzucony ze schodów przez rosyjskiego komendanta (przypadki tego typu zostały zarejestrowane). Sposobem wymierzenia kary szeregowym rosyjskim było

15 W 1809 r. przeciw samowoli i aktom przemocy ze strony wojskowych zaprotestował oficjalnie magistrat krakowski. Zagroził, że w razie braku reakcji komendy miasta na karygodne zachowanie żołnierzy (pobicia, samowolne aresztowanie cywilów itp.) skieruje się ze skargą bezpośrednio do arcyksięcia Ferdynanda jako dowódcy VII Korpusu Austriackiego w Galicji. ANK, Mag I/254, s. 9, 11, 21, $37,55$.

16 ANK, Mag I/250, s. 547; Mag I/238, s. 403-409.

17 ANK, Mag I/222, s. 15, 293-312. Interwencja krakowskich deputowanych na Sejm Księstwa Warszawskiego u Ministra Spraw Wewnętrznych z 26 XII 1812 r. w sprawie niewykorzystania istniejących koszar oraz wywiezienia ich wyposażenia, ufundowanego rok wcześniej przez mieszkańców Krakowa, nie zakończyła się powodzeniem, ibidem.

18 Szerzej zob. J. Przygodzki, Rada Najwyższa Tymczasowa Księstwa Warszawskiego 1813-1815. Organizacja i działalność, Wrocław 2002. 
najczęściej spoliczkowanie przez oficera, po czym sprawę uznawano za zamkniętą. Nic też dziwnego, że awanturujący się, często pijani wojskowi budzili prawdziwy popłoch wśród swoich gospodarzy. Niektóre kobiety porzucały swe mieszkania, uciekając w ten sposób przed „zalotami” wojskowych stojących tam na kwaterach ${ }^{19}$.

Kwaterunek, czyli najczęstsza płaszczyzna kontaktów między cywilnymi mieszkańcami Krakowa a wojskowymi w latach 1796-1815, prowadził w wielu wypadkach do konfliktów, w których stroną silniejszą byli z reguły wojskowi. Na kłopotliwe sprawy bytowe nakładały się tu dodatkowo kwestie polityczno-narodowe, szczególnie widoczne w ostatnich miesiącach panowania austriackiego w 1809 roku oraz w trakcie okupacji rosyjskiej. W wyniku niedostatku lub nawet całkowitego braku koszar w mieście żołnierze, nie mówiąc już o oficerach, żyli razem z cywilnymi mieszkańcami, dzieląc z nimi domy, a nawet mieszkania. Wojsko było widoczne nie tyle na placach ćwiczeń, ile na ulicach miasta i w domach jego obywateli. Najrozmaitsze regulaminowe przepisy dotyczące pobudki, wspólnego posiłku kompanii, codziennego przeglądu oddziałów, capstrzyku itp. okazały się w tych warunkach nie do zrealizowania. Zamiast „wspólnego kotła” żołnierze korzystali z prywatnych kuchni swoich gospodarzy, wraz z nimi szli spać, a następnie wstawali. Chcąc nie chcąc, stawali się cząstkami gospodarstw setek krakowskich rodzin. Jeżeli przedstawiciele obu stron nie potrafili odpowiednio dopasować swojego trybu życia, to droga do konfliktu była otwarta. Czasami winę ponosili cywile. Na przykład w 1810 roku krawcowa Marianna Szwarcowa została oskarżona o to, że nie podawała żołnierzom śniadania, wysyłała ich „do stu tysięcy diabłów”, ,samymi nieprzyzwoitymi słowami swarzyła się" oraz, co w ustach wojskowych tamtej epoki brzmiało już nieco humorystycznie, ,prowadzi[ła] jako mężatka nieprzyzwoite życie”. Krewką krawcową skazano na 24-godzinny areszt i pouczono, by nie hałasowała i nie budziła żołnierzy, gdy o północy wraca do domu ${ }^{20}$.

Jednym z ważniejszych obowiązków ludności cywilnej Krakowa była realizacja zamówień i dostaw na rzecz armii. W związku z tym dochodziło do interakcji pomiędzy kilkoma grupami mieszkańców: urzędnikami, liwerantami, rzemieślnikami a administracją militarną. Dla magistratu, szczególnie w czasach Księstwa Warszawskiego i okupacji rosyjskiej, jednym z podstawowych problemów były starania o obniżenie podatków i świadczeń na rzecz wojska, z których część nakładano w sposób niezgodny z prawem albo też ściągano z rocznym lub dwuletnim wyprzedzeniem. Działania te skutkowały długotrwałym konfliktem pomiędzy magistratem a administracją państwową, realizującą żądania armii. Spór ten w rzeczywistości dotykał wszystkich mieszkańców zobowiązanych do ponoszenia ofiar na rzecz wojska i przyczyniał się do wzrostu nastrojów antymilitarnych ${ }^{21}$. W okresach gwałtownych zbrojeń

19 ANK, Mag I/254, s. 167-469.

20 ANK, II Dyrekcja Policji w Krakowie (dalej: II DPKr), 17, s. 37, 49-54.

${ }_{21}$ W myśl petycji Rady Municypalnej wystosowanej 11 XI 1813 do Rady Najwyższej Tymczasowej wydatki Krakowa (miasta oraz mieszkańców-podatników) na cele państwowe, a w praktyce wojskowe, miały wynieść od VII 1809 do połowy 1814 r. aż 9284000 zł polskich (w tym 6916000 zł polskich w roku podatkowym 1809/1810), co zrujnowało finanse miasta i doprowadziło do ubóstwa jego ludność. ANK, Mag I/44, s. 749-801; PDK 2, vol. 6, k. 122-139. 
$(1805,1809,1813)$ strona wojskowa zachęcała, a następnie zmuszała cechy i korporacje do wydelegowania specjalistów do prac na rzecz wojska, których najczęściej nie opłacano. Nic dziwnego, że dla rzemieślników funkcjonujących w sztywnych strukturach cechowych zlecenia wojskowe nie kojarzyły się z możliwością szybkiego i łatwego zarobku. Ich beneficjentami byli rzutcy przedsiębiorcy, najczęściej Żydzi kazimierscy, którzy potrafili sprawnie zorganizować dostawy alkoholu, mięsa, słomy oraz siana, rozpisane przez administrację wojskową. Na ich tle krakowscy kupcy chrześcijańscy, domagający się zagwarantowania przywilejów i monopoli oraz stałej protekcji ze strony władz, prezentowali się bardzo słabo. W okresach pokoju wojsko pozostawało natomiast istotnym pracodawcą dla większej grupy rzemieślników zatrudnionych przy budowie i remontach koszar, magazynów oraz innych obiektów militarnych w mieście, a także wykonujących prace krawieckie na rzecz Komisji Mundurowej na Podgórzu ${ }^{22}$. Niekiedy realizacja zleceń na rzecz wojska mogła nieść ze sobą nieoczekiwane profity. Przekonała się o tym praczka Jadwiga Rabkowa, która została z bliżej nieokreślonego powodu aresztowana w lipcu 1797 roku na polecenie magistratu, a następnie zwolniona na prośbę Krajowego Komisarza Pościelowego, który dowodził, że jej nieobecność spowodowała całkowitą dezorganizację pracy magazynu wojskowego ${ }^{23}$.

We wszystkich państwach przełomu XVIII i XIX wieku wojsko miało do odegrania istotną funkcję polityczno-propagandową, a także towarzyską. Armia podnosiła prestiż państwa, wpajała mieszkańcom przekonanie o jego sile, uczestniczyła także w różnych uroczystościach oficjalnych, powitaniu monarchów itp. W dużym stopniu powiązane były z tym funkcje pozasłużbowe wojska, głównie korpusu oficerskiego. Miał on w sposób półoficjalny integrować poddanych z państwem, także podczas balów, zabaw i spotkań towarzyskich. To właśnie na tej stopie kontakty cywilów z wojskowymi stawały się szczególnie bliskie, czasem wręcz zażyłe, a zarazem zwiększały stopień akceptacji, wręcz podziwu dla sił zbrojnych. Udział oficerów w różnych imprezach cywilnych był ich półoficjalnym obowiązkiem.

Przykład krakowski nie do końca potwierdza wypełnienie tych zadań. Wojsko wraz z przedstawicielami zarządu miasta i tutejszych elit uczestniczyło wspólnie w oficjalnych uroczystościach (urodzinach, względnie rocznicach koronacji cesarza Franciszka II/I, cesarza Napoleona i króla Fryderyka Augusta oraz cara Aleksandra I), ale tylko obchody z czasów Księstwa Warszawskiego budziły autentyczną sympatię i zaangażowanie mieszkańców Krakowa ${ }^{24}$. Na ten okres przypadały też liczne parady i przeglądy żołnierskie z masowym udziałem publiczności. Powitanie wojsk polskich w lipcu 1809 i w lutym 1813 roku oraz wymarsz większości załogi w maju 1811, a całej armii polskiej w maju 1813, stały się dla mieszkańców okazjami do spontanicznych manifestacji swojego przywiązania do wojsk narodowych ${ }^{25}$. Do le-

22 ANK, Mag I/248, s. 453, 461, 491-505, 521-675.

23 ANK, Mag I/236, s. 27.

24 K. Bąkowski, Kronika Krakowska 1796-1848, cz. I: 1796-1815, Kraków 1905, s. 10, 28, 40; „Gazeta Krakowska” 1796, nr 34; 1809, nr 14, 20-21, 76.

25 [J. Weyssenhoff], Pamiętnik generała Weyssenhoffa, Warszawa 1904, s. 132; A. Białkowski, Pamiętniki starego żolnierza (1806-1814), Warszawa 1903, s. 278, 285-287; K. Brodziński, Wspo- 
gendy przeszedł krakowski karnawał w 1813 roku, kiedy to weterani wyprawy na Moskwę bawili się wieczorami i nocami na balach i przyjęciach w mieście, a za dnia uczestniczyli w trudzie odbudowy armii polskiej. Niektórzy, jak słynny major Jan Kozietulski z pułku lekkokonnych Gwardii Napoleona, przypłacili te hulanki utratą zdrowia. Należy zarazem podkreślić, że w charakterze cywilnych gospodarzy występowali często arystokraci i przedstawiciele administracji cywilnej Księstwa Warszawskiego, niemający na co dzień wiele wspólnego z Krakowem.

Udział wojskowych polskich w życiu towarzyskim Krakowa miał specyficzny charakter: oficerowie szukali przede wszystkim swoich partnerów (partnerek) wśród arystokracji i zamożnego ziemiaństwa, które nie było w Krakowie zbyt liczne, chociaż ogólną liczbę zamieszkującej tu szlachty można uznać za całkiem pokaźną (474 osoby płci męskiej pochodzenia szlacheckiego w maju 1808 r.) ${ }^{26}$. Pod względem życia towarzyskiego stołeczna Warszawa była miejscem o wiele bardziej atrakcyjnym, o czym bez ogródek pisał pułkownik Jan Weyssenhoff, który w latach 1809-1811 stacjonował ze swoim pułkiem w Krakowie ${ }^{27}$. Na mieszczaństwo oficerowie patrzyli zwykle z góry, a bariery stanowe okazały się trudne do przełamania. Ponadto brutalnie formułowane żądania natychmiastowego dostarczenia niemal wszystkich możliwych towarów dla wojsk polskich w pierwszych dniach po wyzwoleniu z rąk austriackich szybko ochłodziły entuzjazm wynikający z wkroczenia armii narodowej, o czym szczerze pisała między innymi Wirydianna Fiszerowa, żona szefa sztabu wojsk polskich ${ }^{28}$. Słynny bal urządzony w Sukiennicach 15 sierpnia 1809 roku miał być nawet swego rodzaju „świętem pojednania” krakowskiego mieszczaństwa z korpusem oficerskim. Sam fakt, że w ten sposób interpretowano to wydarzenie, pokazuje, że stosunki towarzyskie między oficerami a elitami mieszczańskiego Krakowa nie zawsze były idealne.

Armie austriacka i rosyjska nie budziły w mieście żadnych pozytywnych skojarzeń, choć gapiów obserwujących ich kolorowe oddziały nigdy nie brakowało. Informacji o udziale wojskowych z armii zaborczych w życiu towarzyskim Krakowa (poza oficjalnymi balami i wizytami w teatrze) zupełnie brak ${ }^{29}$.

Nieco inaczej należy traktować częste kontakty oficerów i żołnierzy z krakowskimi prostytutkami. Wojskowi zaliczali się do głównych klientów „kobiet publicznych", ale to oficerowie i szeregowcy rosyjscy byli szczególnie zainteresowani kontaktami z nimi. Doprowadziło to do gwałtownego deficytu podaży kobiet. Prości żołnierze posunęli się nawet do kilkukrotnego szturmowania szpitala wenerycznego, w którym przebywały zarażone „kobiety publiczne”. Rezultaty były dość łatwe do

mnienia mojej młodości i inne pisma autobiograficzne, Kraków 1928, s. 71-72.

26 ANK, Mag I/190, s. 351.

27 [J. Weys senhoff], op. cit., s. 127.

28 W. Fiszerow a, Dzieje moje własne, Warszawa 1998, s. 348.

29 Nieliczne wzmianki na temat armii austriackiej pojawiające się na łamach „Gazety Krakowskiej” w latach 1796-1809 w praktyce nic nie wnoszą do tematu. Po wyzwoleniu Krakowa z rąk austriackich redaktor pisma Jan Maj zamieścił swoje przeprosiny za to, że rząd austriacki ,zniewolił do wypisywania z jego gazet uszczypliwych artykułów przeciw Osobie Najjaśniejszego Cesarza Napoleona, jego czynom i własnym nawet rodakom; nadto gotowe artykuły niemiecką polszczyzną tłumaczone przesłał mu do umieszczania”. „Gazeta Krakowska” 1809, nr 57. 
przewidzenia: krakowskie prostytutki zaraziły chorobami wenerycznymi znaczną część załogi rosyjskiej, doprowadzając w 1815 roku do jej poważnego osłabienia i faktycznej dezorganizacji, o czym bez ogródek pisał komendant załogi carskiej ${ }^{30}$. Trudno nie oprzeć się wrażeniu, że krakowskie panie lekkich obyczajów stały się większym zagrożeniem dla armii rosyjskiej niż polscy żołnierze walczący z nią na polach Niemiec i Francji.

Obecność licznej załogi w bezpośredni sposób wpływała na kwestię bezpieczeństwa wewnętrznego. Żołnierzy „używano” w charakterze policji do kontroli ruchu ludności, wyłapywania włóczęgów, ludzi „luźnych” i nielegalnych prostytutek, a także jako straż pożarną. Oznaczać to powinno zredukowanie liczby aktów przestępczych w mieście. Realizacja tych zadań przebiegała w zróżnicowany sposób. O ile wojsko austriackie dość rygorystycznie przestrzegało obowiązujących zasad, o tyle wielu polskich szeregowców wojsk Księstwa Warszawskiego przymykało oko na drobne wykroczenia i samowolnie wypuszczało z aresztu podejrzanych o włóczęgostwo czy lekceważenie przepisów policyjnych, a już zwłaszcza panie lekkich obyczajów ${ }^{31}$. Działania takie budziły oburzenie statecznego mieszczaństwa, ale jednocześnie przysporzyły popularności wojsku narodowemu w środowiskach plebejskich.

W wielu wypadkach sami wojskowi czynnie uczestniczyli w rozbojach, napadach i kradzieżach, których ofiarami padali cywilni mieszkańcy Krakowa. Samowolny zabór mienia (żywności, sprzętów gospodarskich, drewna) na potrzeby wojskowe był jedną z plag spadających na ludność. W czasie okupacji rosyjskiej liczba przestępstw popełnianych na cywilach przez żołnierzy, w tym kradzieży, gwałtownie wzrosła. Niektórzy bronili się przed nimi w drastyczny sposób. Dochodziło do burd i bijatyk. W rezultacie zanotowano przypadki morderstw, względnie zaginięcia bez śladu, zarówno wojskowych carskich, jak i mieszczan krakowskich. Najczęściej kontakty na linii wojsko rosyjskie-cywile krakowscy miały właśnie charakter przestępczy, a poszkodowanymi byli z reguły mieszkańcy Krakowa ${ }^{32}$.

Przestępczość pospolita żołnierzy wyraźnie wzrastała, gdy nakładał się na nią konflikt o charakterze politycznym i narodowościowym. Sytuacje takie stały się szczególnie widoczne podczas wojen 1809 roku (wojsko austriackie) i w latach 1813-1814 (wojsko rosyjskie) ${ }^{33}$. W obydwu przypadkach ludność Krakowa potraktowano jako potencjalnych rebeliantów i wrogów. Nic też dziwnego, że próby przeciwstawienia się aktom o charakterze przestępczym prowadziły do pobić i aresztowań ofiar tych napadów. Interwencje u najwyższych władz wojskowych nie zawsze prowadziły do pomyślnego rozwiązania, a wszczynane przed sądami militarnymi postępowania śledcze kończyły się najczęściej konkluzją o braku winy ze strony żołnierzy lub o niemożliwości wykrycia sprawców.

30 Zob. ANK, Mag I/379, s. 1-1345, a zwłaszcza s. 1049 (pismo gen. Skuriatina do prezydenta S. Zarzeckiego).

31 ANK, II DPKr, 17, s. 15, 38.

32 Ze strony rosyjskiej zginął $\mathrm{w}$ nieznanych okolicznościach ataman kozacki Jakub Kaliman, a w rewanżu żołnierze rosyjscy zabili mieszczanina Macieja Bogackiego; szerzej zob. ANK, Mag I/254, s. $167-469$.

33 Ibidem, s. 37, 55. 
Lektura materiałów archiwalnych z lat 1796-1815 wskazuje, że stosunki między mieszkańcami Krakowa a załogą wojskową stacjonującą w mieście były intensywne, ale trudne. Liczba płaszczyzn konfliktu pozostawała znaczna, a władze wojskowe na ogół nie dążyły do ich rozwiązania na drodze kompromisu, stale domagając się kwater, żywności, świadczeń w materiale i robociźnie. Stosunkowo najwięcej zrozumienia dla interesów miasta i jego ludności okazywały władze austriackie (poza kampanią 1809 r.). Władze administracyjne i generalicja Księstwa Warszawskiego niemal zupełnie lekceważyły te kwestie, niemniej wspólnota idei niepodległościowej wśród armii i cywilów oraz brak bariery językowej w decydujący sposób wpływały na ocieplenie wzajemnych kontaktów. Okupacja rosyjska przyniosła ze sobą wszelkie negatywne skutki posiadania garnizonu wojskowego, i to mimo starań cara Aleksandra I oraz Rady Najwyższej Tymczasowej o pozyskanie Polaków. Proklamacja Wolnego, Niepodległego i Ściśle Neutralnego Wolnego Miasta Krakowa, a przy tym pozbawionego załogi wojskowej, wywołała więc niekłamaną radość mieszkańców.

\section{BIBLIOGRAFIA}

\section{Źródła archiwalne}

Archiwum Narodowe w Krakowie (ANK)

II Dyrekcja Policji w Krakowie (II DPKr), 17.

Magistrat Krakowa I (Mag I), 44, 190, 221, 222, 225, 229, 230, 233, 236, 238, 248, 250, 254, 379, 782, 783.

Prefektura Departamentu Krakowskiego (PDK), 1, 2.

Varia Krakowa i Okręgu Krakowskiego (VKOK), 607, 608.

Österreichisches Staatsarchiv/Kriegsarchiv Wien (ÖStA/KA)

Kriegsminister Lacy Akten (KLA), fasc. 299/13, 302/11, 332/19.

\section{Źródła drukowane i opracowania}

Amon von Treuenfest G., Geschichte des k.k. Infanterie-Regiments Nr. 20 Friedrich Wilhelm Kronprinz des Deutschen Reich und Kronprinz von Preussen, Wien 1878.

Baczkowski M., Wojsko austriackie w Krakowie w latach 1796-1809, Kraków 2007.

Baczkowski M., Wojsko polskie w napoleońskim Krakowie, Kraków 2009.

Bąkowski K., Kronika Krakowska 1796-1848, cz. I: 1796-1815, Kraków 1905.

Białkowski A., Pamiętniki starego żotnierza (1806-1814), Warszawa 1903.

Bichmann W., Chronik des k.k. Infanterie-Regiments Nr. 62 dermalen Ludwig Prinz von

Bayern von seiner Errichtung 1798 bis 1880, Wien 1880.

Brandt H., Moja stużba w Legii Nadwiślańskiej, Gdynia 2002. 
Brodziński K., Wspomnienia mojej młodości i inne pisma autobiograficzne, Kraków 1928. Fiszerowa W., Dzieje moje własne, Warszawa 1998.

„Gazeta Krakowska” 1796, nr 34; 1809, nr 14, 20-21, 76.

Geschichte des kaiserlichen und königlichen Infanterie-Regiment Freiherr von Mollinary Nr. 38, seit seiner Errichtung 1725 bis 1891, Budapest 1892.

Kreipner J., Geschichte des k. und k. Infanterie-Regimentes Nr. 34 für immerwährende Zeiten Wilhelm I Deutscher Kaiser und König von Preussen 1733-1900, Wien 1900.

Krzos K., Z księciem Józefem w Galicji w 1809 roku. Rząd Centralny Obojga Galicji, Warszawa 1967.

Mencel T., Galicja Zachodnia 1796-1809. Studium z dziejów ziem polskich zaboru austriackiego po III rozbiorze, Lublin 1976.

Österreichischer Militär Almanach, 1797-1803, (następnie pod nazwą Schematismus der Kais. Königl. Armée: für das Jahr, 1804-1809), Wien 1797-1809.

Pawłowski B., Wojna polsko-austriacka 1809 r., Warszawa 1999.

Przygodzki J., Rada Najwyższa Tymczasowa Księstwa Warszawskiego 1813-1815. Organizacja i działalność, Wrocław 2002.

Rederowa D., Studia nad wewnętrznymi dziejami Krakowa porozbiorowego (1796-1809), cz. II: Zagadnienia ustrojowe i ekonomiczno-społeczne, „Rocznik Krakowski” 1962, t. XXXVI.

Tomkowicz S., Wawel, t. I, Kraków 1908, t. II, Kraków 1913.

[Weyssenhoff J.], Pamiętnik generała Weyssenhoffa, Warszawa 1904.

Wrede A. von, Geschichte der k. u. k. Wehrmacht, Bd. I-III, Wien 1898-1901. 